\title{
EVALUATION OF FERTILITY INDEX OF WATERSHEDS IN RAYALASEEMA REGION
}

\author{
T. Kiran Kumar ${ }^{1}$, N. Kumara Swamy ${ }^{2}$ \\ ${ }^{1}$ Associate Professor of Civil Engg, K.S.R.M. College of Engineering, Kadapa - 516 003, A.P. - India \\ ${ }^{2}$ Principal, Vaagdevi Inst.of Technology \& Science, Proddatur, Kadapa Dist., A.P. - India
}

\begin{abstract}
Nature made the soil as a self-renewable natural resource material so far as its fertility is concerned; but, its misuse and overuse, man has disturbed this balance of nature. He has not returned back faithfully what he took from the soil. Basic information on soils has advanced at a tremendous rate, but wisdom in their management, to those who till them, has been slow to come. The result has been rapid decline in soil fertility, fall in yields per acre and insufficient agricultural production in India, particularly so within the last few decades.
\end{abstract}

Fertility in the soil is the result of the presence in it of essential plant nutrients, both major and minor, in adequate amounts and in forms which plants can utilize. In addition, the organic matter in the soil, with its resulting physical and microbiological benefits, is also highly important as it makes the soil a living body. It is necessary to know what the present status of these soil fertility elements is; how they decrease or increase; and what are the ways by which they can be maintained in the forms and at levels which can give high crop production is long-term use.

In this paper, an attempt has been made to evaluated the fertility status in watersheds of Kadapa drought prone mandals. Based on fertilize index suggested suitable crops and also required fertilizers for improve the strength of the soil and crop yield.

Keywords: self-renewable, fertility, physical and microbiological benefits.

\section{INTRODUCTION}

The soil is the very foundation of life. It supplies the people with food, fodder, clothing and shelter. All that a man eats vegetables, grains, milk, eggs, meat or fruits - all that he clothes himself with whether woolens, silkens or cottons and all that he feeds his animals with, come from the fertility released by the soil. The fertility of the soil is, therefore, basic to all human existence. It is in fact the foundation of all life on earth and of civilization in the entire world. Those who dwell in villages as well as those who live in towns - rather the Nation as a whole - have a big stake in their soil and in its fertility. Our soils must be kept in a high level of fertility and made productive or the foundation of life will crumble and our civilization will perish. People living on poor or worn-out soils have poor health and are poverty stricken; those who farm fertile and productive soils are in better health and are more prosperous. Races of men are, therefore, the finished products of the landscape and their development depends on adjustment to the quality of the soils which they inhabit. A distinct race comes up on a distinct soil. The maintenance of the soil which is the chief medium for production of crops is fundamental to the wellbeing of the human race. A study of the fertility of soil has unquestionably the highest importance to understanding many complex problems concerning agriculture of a country. $* * *$

Soil fertility should not be confused with soil productivity. In almost all treatments on the subject of soil fertility, people prefer to make distinction between the two words. Since soil fertility is defined as the ability of a soil to produce a certain yield of crops, it depends on those factors in the soil that determine its crop production potential. Such factors are the presence of essential plant nutrients in available forms and in a suitable balance; the proper microbiological status of the soil to provide healthy environment for the release of plant nutrients; and freedom from any toxic or injurious agents, conditions or substances in soil. A soil may be fertile and yet it may not be productive. Thus, a water-logged soil may be highly fertile but may not produce good crops because of the unfavourable physical conditions. Similarly, a fertile soil may have saline, alkali or boron salts, which being toxic to plant growth, restrict its potential power to produce crops. Conversely, a sandy soil poor in fertility may, through the use of fertilizers and water, produce high crop yields. Excess of any injurious substance or toxic principles in the soil may lower, in some areas, the otherwise high crop producing ability of the soil. Besides these factors, there are others which are more or less constant under a set of conditions and can not be influenced by human endeavour. These are the nature and type of the soil and the climate where such soil exists. Amongst the soil factors uncontrollable by man are characters such as topography, soil texture, depth of soil profile, etc. Similarly, the climatic factors such as temperature, light intensity, evaporation, frost, etc., are beyond the influence of human agencies. Precipitation, both the total or its distribution in a 
locality can, however, be supplemented by artificial irrigation wherever such facilities have been made available. Evidently, in a discussion on soil fertility only those factors are of importance that are within the influence of man and the judicious control of which determines the maximum crop yields in any given soil situated in a particular climatic location. Wise soil management depends on the correct adaptation of these factors to get the best possible advantage of the existing soil fertility. In brief, soil fertility is the potential status of a soil to produce crops; while soil productivity is the resultant of various factors influencing soil management.

Soil fertility is the most valuable asset of a nation can possess. It should be maintained where it is high, improved where it is low and developed where it is lacking. Soil fertility is of two kinds, viz., permanent fertility and temporary fertility. Permanent fertility is inherent in the soil itself and temporary fertility is acquired by suitable management treatments. But the response to outside treatments to build up soil fertility is highly dependent on the degree of permanent fertility that is already there. However, we know that permanent fertility can be improved, maintained or impaired according to the practices that we employ in our soil management. Thus, a knowledge of both the permanent fertility status of the soil and the ways and means by which it can build up temporary fertility, to assist us in crop production, is the essential basic technology of wise soil management.

\section{METHODOLOGY}

Soil is the greatest natural resource gifted to mankind. Crop yield depends on fertility of soil, fertility content in a soil is frequently varied due to climate conditions. Hence, study of fertility status of soil in watershed is essential to estimate productivity of any watershed programme.
The fertility index of a watershed was varied from a watershed to another watershed before and after watershed programme due to chainage in construction of soil activities and climate conditions.

The details of the available nutrient status of various watersheds are collected from Joint Director of Agriculture Department, Kadapa. The fertility index of various watersheds was calculated based on collected data. Based on fertility index, suggest suitable crop and required quantity of fertilizers are recommended for each watershed.

The overall availability status of a particular nutrients in given area were classified as low, medium and high categories. (A training manual published by Natural Council of Agricultural, New Delhi)

The fertility index was calculated by using the following formula

$$
=\frac{(N L \times 1)+(N M \times 2)+(N H \times 3)}{N T}
$$

Where NL, NM, and NH are the numbers of soil samples falling in low, medium and high categories and NT is the total number of sample.

$\begin{array}{cc}\text { Fertility Index } & \text { Fertility Status } \\ 0-1.66 & \text { Low } \\ 1.66-2.33 & \text { Medium } \\ >2.33 & \text { High }\end{array}$

The fertility index of the soils in the various watersheds before and after the programme are presented in the table 1.

\section{RESULTS \& DISCUSSIONS}

The fertility index of the soils before and after the watershed programme are presented in table 1

Table 1: shows the Fertility Index of Soil Nutrients of various watersheds

\begin{tabular}{|l|l|l|l|l|l|l|l|}
\hline \multirow{2}{*}{$\begin{array}{l}\text { So. } \\
\text { Nome of the watershed }\end{array}$} & Name & \multicolumn{2}{l}{$\begin{array}{l}\text { Availability of } \\
\text { Nitrogen }\end{array}$} & \multicolumn{2}{l}{$\begin{array}{l}\text { Availability } \\
\text { Phosphorous }\end{array}$} & $\begin{array}{l}\text { Availability } \\
\text { Potassium }\end{array}$ \\
\cline { 3 - 8 } & & Before & After & Before & After & Before & After \\
\hline 1. & Chilamkuru & 1.25 & 1.65 & 1.24 & 1.86 & 2.54 & 2.64 \\
\hline 2. & Kothapalli & 1.38 & 1.58 & 1.25 & 1.78 & 2.50 & 2.94 \\
\hline 3. & Duvvuru & 1.40 & 1.60 & 1.25 & 1.75 & 2.40 & 2.78 \\
\hline 4. & Dasari Palli & 1.20 & 1.75 & 1.45 & 1.74 & 1.90 & 2.40 \\
\hline 5. & Pandirlapalli & 1.68 & 1.68 & 1.70 & 1.70 & 2.04 & 2.40 \\
\hline 6. & Nallaguttapalli & 1.80 & 1.83 & 1.70 & 1.50 & 2.20 & 2.35 \\
\hline 7. & Yalamakurivari palli & 1.50 & 1.22 & 1.20 & 1.50 & 2.60 & 2.30 \\
\hline 8. & Kodur & 1.20 & 1.50 & 1.17 & 1.50 & 2.00 & 2.40 \\
\hline 9. & Shintakutta & 1.62 & 1.62 & 1.80 & 1.91 & 2.30 & 2.80 \\
\hline 10. & Verapalli & 1.40 & 1.62 & 1.27 & 1.80 & 2.48 & 2.90 \\
\hline 11. & Kondasunkesala & 1.40 & 1.62 & 1.10 & 1.70 & 2.28 & 2.75 \\
\hline 12. & E.Kothapalli & 1.50 & 1.60 & 1.80 & 1.82 & 2.00 & 2.30 \\
\hline
\end{tabular}


Nitrogen fertility index of various watersheds varies from 1.25 to 1.80 before starting the programme. However the percentage of variation of nitrogen fertility index after completion of the watershed programme is ranging from 1.65 to $1.83,70 \%$ of the watershed soils have deficiency of nitrogen because much of the nitrogen is also lost from the soil, besides what is taken up by the growing crops or locked up by synthesis into microbial bodies. A part of the soil nitrogen is converted into volatile forms, as ammonia, or in the elementary form, as nitrogen gas, and escapes into the air. A part of nitrates, is leached out of the soil. The three phases of nitrogen losses, i.e., through ammonia, as elementary nitrogen or as nitrates, are of importance in the nitrogen economy of environment, and in the maintenance of soil fertility.

Nitrogen is lost either through spontaneous decomposition of ammonical salts or through the interaction of nitrates with ammonia bodies present in the soil. Nitrates may also be denitrified in the presence of undecomposed organic matter purely as a bacterial process under limited oxygen supply.

Nitrogen deficiency can be observed by knowing following symptoms (i) pale yellowish colour of the entire crop, (ii) slow and dwarfed growth of plants and (iii), yellowing of leaves, which in cereals and grasses starts from the tip, proceeding down the center along the mid-rid, leaving the outer area greener.

Phosphorous fertility index of various watersheds varies from 1.10 to 1.80 before starting the programme. However, the percentage of variation of phosphorous fertility index after completion of the watershed programme is range from 1.5 to 1.86 . $25 \%$ of the watersheds soils have deficiency of phosphorous. The loss of phosphorous from the soil has been occurred due to the leaching, formation, and through soil erosion particularly in sandy soils. As per research estimation in India, agricultural crops removes $3 \mathrm{MT}$ nitrogen, 1.5MT phosphorous acid and 3.5MT of potassium per each year. Phosphorus is not a very mobile nutrient in the soil, which is a fairly mobile nutrient in the plant organism. After absorption from the soil solution, the concentration of inorganic phosphorous in the cell sap of the plant becomes several thousand time higher than that in the soil solution. After absorption from the soil phosphorus can be found in greater proportions in the reproductive parts of the plant and hence the seeds of crops, obtaining adequate supplies of phosphorus, get richer in phosphorus thus adding to the nutritive quality of the grain.

As a consequence of greater cell division, stronger root system and more strength to the straw caused by phosphorus, the crop gets the extra capacity to resist attack of diseases.

The typical nutrient deficiency are identified in various watersheds and suggested suitable fertilizers are presented in table 2. From the table 1 it is observed that the soils in various watersheds contains high deficiency of nitrogen. This is probably due to heavy rainfall and plant absorb nutrients, due to erosion and also due to evaporation losses. However, the phosphorous deficiency is medium level compared to nitrogen based on fertility index and fertility chart required fertilizers to enhance the crop yield and suggested to the formers based on the fertility recommendation chart. Prepared by the Indian Agricultural Research Council, Hyderabad [Reddy, K.C.K. et.al 1974).

The suitable crops and required fertilizers are recommend for various watersheds soils based on fertility index and opinion of senior agricultural scientists and field officers of Agricultural department.

Table 2: shows the suggested Fertilizers and crops in the study area

\begin{tabular}{|c|c|c|c|c|c|c|c|c|c|}
\hline \multirow{2}{*}{$\begin{array}{l}\text { S. } \\
\text { No. }\end{array}$} & \multirow{2}{*}{$\begin{array}{l}\text { Name of the } \\
\text { Watershed }\end{array}$} & \multirow{2}{*}{$\begin{array}{ll}\text { Typical } & \text { Nutrient } \\
\text { Status } & \end{array}$} & \multirow{2}{*}{$\begin{array}{l}\text { Suggested } \\
\text { crops }\end{array}$} & \multicolumn{6}{|c|}{ Suggested Fertilizer (kg/Acre) } \\
\hline & & & & $\mathrm{N}$ & $\mathrm{P}$ & $\mathrm{K}$ & Urea & SSP & MOP \\
\hline \multirow[t]{4}{*}{1.} & \multirow[t]{4}{*}{ Chilamkuru } & \multirow[t]{4}{*}{ Low Nitrogen } & Ground nut & 11 & & & 24 & & \\
\hline & & & Red gram & 11 & & & 24 & & \\
\hline & & & Cotton & 21 & & & 46 & & \\
\hline & & & Bajra & 32 & & & 70 & & \\
\hline \multirow[t]{3}{*}{2.} & \multirow[t]{3}{*}{ Kothapalli } & \multirow{3}{*}{$\begin{array}{l}\text { Low Nitrogen \& } \\
\text { Medium } \\
\text { Phosphorous }\end{array}$} & Paddy & 43 & 24 & & 93 & 150 & \\
\hline & & & Groundnut & 43 & 16 & & 24 & 40 & \\
\hline & & & Red gram & 11 & 20 & & 24 & 125 & \\
\hline \multirow[t]{2}{*}{3.} & \multirow[t]{2}{*}{ Duvvuru } & \multirow{2}{*}{$\begin{array}{l}\text { Low Nitrogen, } \\
\text { Low Phosphorous }\end{array}$} & Cotton & 21 & 11 & & 46 & 69 & \\
\hline & & & Paddy & 43 & 32 & & 93 & 200 & \\
\hline \multirow[t]{3}{*}{4.} & \multirow[t]{3}{*}{ Dasari Palli } & \multirow{3}{*}{$\begin{array}{l}\text { Medium } \\
\text { Phosphorus, High } \\
\text { Potassium }\end{array}$} & Paddy & & 11 & 24 & & 150 & 18 \\
\hline & & & Ground nut & & 11 & 16 & & 150 & 18 \\
\hline & & & Castor & & 8 & 16 & & 100 & 13 \\
\hline \multirow[t]{3}{*}{5} & \multirow[t]{3}{*}{ Pandirlapalli } & \multirow{3}{*}{$\begin{array}{l}\text { Low Nitrogen } \\
\text { Medium } \\
\text { Phosphorus }\end{array}$} & Groundnut & 11 & 16 & & 24 & 100 & \\
\hline & & & Red gram & 11 & 20 & & 24 & 125 & \\
\hline & & & Cotton & 21 & 08 & & 46 & 50 & \\
\hline \multirow[t]{2}{*}{6.} & \multirow[t]{2}{*}{ Nallaguttapalli } & \multirow{2}{*}{$\begin{array}{l}\text { Medium Nitrogen } \\
\text { Low Phosphorus }\end{array}$} & Paddy & 43 & 11 & & 93 & 27 & \\
\hline & & & Red gram & 11 & & & 24 & & \\
\hline \multirow[t]{2}{*}{7.} & \multirow{2}{*}{$\begin{array}{l}\text { Yalamakurivari } \\
\text { palli }\end{array}$} & \multirow{2}{*}{$\begin{array}{l}\text { Low Nitrogen, } \\
\text { Low Phosphorous }\end{array}$} & Paddy & 43 & 32 & & 93 & 200 & \\
\hline & & & Groundnut & 11 & 21 & & 24 & 131 & \\
\hline
\end{tabular}




\begin{tabular}{|c|c|c|c|c|c|c|c|}
\hline & & & Red gram & 11 & 11 & 24 & 27 \\
\hline \multirow[t]{3}{*}{8.} & \multirow[t]{3}{*}{ Kodur } & \multirow{3}{*}{$\begin{array}{l}\text { Low Nitrogen, } \\
\text { Low Phosphorous }\end{array}$} & Paddy & 43 & 32 & 93 & 200 \\
\hline & & & Sunflower & 32 & 48 & 70 & 200 \\
\hline & & & Sesamun & 32 & 32 & 70 & 200 \\
\hline \multirow[t]{2}{*}{9.} & \multirow[t]{2}{*}{ Chintakutta } & \multirow[t]{2}{*}{ Low Nitrogen } & Cotton & 21 & & 46 & \\
\hline & & & Paddy & 43 & & 93 & \\
\hline \multirow[t]{3}{*}{10.} & \multirow[t]{3}{*}{ Veeraballi } & \multirow[t]{3}{*}{ Low Nitrogen } & Paddy & 43 & & 93 & \\
\hline & & & Groundnut & 11 & & 24 & \\
\hline & & & Red gram & 11 & & 24 & \\
\hline \multirow[t]{3}{*}{11.} & \multirow[t]{3}{*}{ Kondasunkesala } & \multirow{3}{*}{$\begin{array}{l}\text { Low Nitrogen, } \\
\text { Medium } \\
\text { Phosphorous }\end{array}$} & Paddy & 43 & 24 & 93 & 150 \\
\hline & & & Groundnut & 11 & 16 & 24 & 100 \\
\hline & & & Cotton & 32 & 16 & 70 & 100 \\
\hline \multirow[t]{2}{*}{12.} & \multirow[t]{2}{*}{ E.Kothapalli } & \multirow{2}{*}{$\begin{array}{l}\text { Low Nitrogen, } \\
\text { Medium } \\
\text { Phosphorous }\end{array}$} & Groundnut & 11 & 16 & 24 & 100 \\
\hline & & & Sunflower & 32 & 24 & 70 & 150 \\
\hline
\end{tabular}

\section{CONCLUSION}

$70 \%$ of watershed soils have deficiency of Nitrogen because much of the nitrogen is loss from the soil besides what is taken up by the growing crops are locked up by synthesis into microbial bodies. Phosphorus fertility index of various watersheds varies from 1.10 to 1.80 before starting the program and 1.50 to 1.86 after completion of the program. $25 \%$ of watershed soils have deficiency of phosphorous due to the leaching formation and through soil erosion.

\section{REFERENCES}

[1] Mukerji, JH.N. (1955) "Potassium in Tropical Soils": Potash Symp. Internal Pot, Inst. Bern.

[2] Raychaudhuri, S.P. (953) "Agricultural Practices in Ancient India", I.C.A.R. Review series No.4.

[3] Yawalkar, K.S., and Agarwal. J.P. (1962) Manures and Fertilizers, Agri. Horti. Pub. House, Nagpur.

[4] Acharya, C.N., and Rajgopalan, K. (1956) J. Indian Soc. Soil Sci., 4, 111.

[5] Chaudhuri, H. (1940) - Nature, 145, 936.

[6] Clarks, G., et al (1922) Agric. J. India 17, 463

[7] Agarwal, R.R., and Mehrotra, C.L. (1956) Soil Survey and Soil Work in U.P., 3 Govt. Printing Press, Allahabad.

[8] Panse, V.G., Dendawte, N.D., and Bokil, S.D., (1947) Summary of Past Manurial works.

[9] Fertilizer Recommendation chart supplied by the Indian Agricultural Research council Hyderabad [Reddy KCK et al (1947)].

[10] A training manual and methodology (2007) published by agricultural department, New Delhi and N.G. Ranga Agricultural University Department of Agricultural Hyderabad, pp.326-335. 